\title{
Evaluation of Some Motoric Parameters of Pre-School Gymnasts and Their Relations
}

\author{
Sezen Çimen Polat ${ }^{1^{*}}$ \\ ${ }^{1}$ Gazi University, Abant sok. No: 12, Yenimahalle, 06330 Ankara, TURKEY \\ *Corresponding Author: sezencimen@gazi.edu.tr \\ Citation: Çimen Polat, S. (2018). Evaluation of Some Motoric Parameters of Pre-School Gymnasts and \\ Their Relations. Pedagogical Research, 3(3), 09. https://doi.org/10.20897/pr/2664
}

Published: September 21, 2018

\begin{abstract}
The aim of this study is to determine the motoric parameters of pre-school gymnasts and investigate the relations between them. 30 gymnasts participated in a research at the age of $7.23 \pm 1.50$. In the research data regarding resting pulse rate, blood pressure, height, weight, flamingo balance test, plate tapping test, standing long jump, shuttle movement, sit and reach flexibility test, hand dynamometer, hanging with bent arm and 10x5 m running were evaluated. Descriptive statistics were performed for all data obtained from research. Pearson's correlation coefficient is calculated to study the direction and strength of the linear relation between the variables with normal distribution and Spearman Rank correlation coefficient is calculated for those who are not normally distributed. In this study the relations between long jump and 10x5 m, plate tapping test and long jump, flamingo balance performance and long jump, flamingo balance performance and plate tapping test also plate tapping test and sit and reach are investigated. An inverse correlation is found between long jump and 10x5 $\mathrm{m}$ and also between long jump and plate tapping test. It is concluded that there is an inverse relation between flamingo balance test with plate tapping test and plate tapping test with sit and reach flexibility test. Same directional relationship is only determined between long jump with flamingo balance test.
\end{abstract}

Keywords: eurofit test, gymnastic, motoric parameters

\section{INTRODUCTION}

Rhythmic Gymnastics is the sport which contains beauty and grace that combines using of rope, ball, hoop, clubs and ribbon along with body movements and dance (Santos et al., 2015). As technical composition plays an important role in rhytmic gymnastics, training from a young age is needed in order to provide basic technical skills and coordinative skill work at a satisfactory level. Because of that it requires the hallway from a young age to perform at the desired level of basic technical skills and coordinative skills work (Bulca and Ersöz, 2004). Composition assessment plays a very important role in ensuring the success of high-level athletes (Doğan, 1986). These compositions require the development of a high level of motor skills, flexibility, strength, endurance, coordination, agility, balance and rhythm (Santos et al., 2015). Almost every movement technique necessitates, various power applications, speed, endurance and coordination features correctly and in a timely manner in gymnastics (Bağc1 et al., 2006). Therefore, an appropriate strength, quickness, and endurance is the prerequisite for success in gymnastics (Ünal et al., 2006). Force is the most important motor characteristics. It can be defined as the ability of overcoming a certain resistance or meet it with muscle tension (Özer, 1989). Athletes may use self body weight and power from movement speed as resistence in rhythmic gymnastics. Changes in the flow and movement in normal tarining pace may cause to the formation of dynamic force. Also static balance stands are compulsory basic body elements which are required to be included in the composition in rhythmic gymnastics. In 
this sport, the movements in the composition include dynamic and static diversity (Kutlay, 1999). Speed is defined as the ability of gymnast to move herself from a place to another place at the highest speed (Sevim, 2010). Speed is one of the motoric abilities which determines the efficiency in the sports but it mainly depends on individual's heritage and hard to be improved when compared with other skills. Certain level of speed is needed to succeed in any kind of sports (Dündar, 2003). Speed in the rhytmic gymnastics is implemented in an environment where movement, rhythm and tempo rapidly change. Distinctive speed can be improved by increasing the speed and rhytm of the movement. Therefore, increase in the speed of sequential movements is important as well as the execution of technical structure during the execution of the composition. This revealed the need for speed ability (Doğan and Altay, 1996). Endurance is the ability of executing a dynamic or static loading as long as possible, without lowering the quality (Elibol, 2000). Endurance plays an important role in almost all sports in its various forms. It is very important in terms of competition performance, ability to resist the fatigue caused by long lasting dynamic or static workouts and recovery. Therefore, the movement speed increase from, as well as the implementation of structural technical movements repeatedly presentation is also important. This has created the need for speed ability (Doğan and Altay, 1996). Endurance work without lowering the quality of static or dynamic loading, the ability to make as long as possible (Elibol, 2000). Durability plays an important role in almost all sports in its various forms, is very important in terms of both competitions power continue loading and long time in both training the dynamics or the ability to resist fatigue given by the static operation and recovery. Gymnastics is not an endurance sport itself but endurance is one of the factors that helps in achieving succesful results in gymnastics (Bağc1 et al., 2006). Flexibility is the ability of a gymnast to execute the movements in a wide angle to different directions to the extent that her joints allow (Sevinç, 2008). Flexibility is not important in any sports than it is in gymastics. A gymnast needs to be preeminently flexible to achieve a performance that includes wideness and elegance (Mengütay, 1998). Flexibility is also important for all other sports as it gives wide motive power to muscle groups and also prevents injuries (Mengütay, 1998). Coordination is the execution of voluntary and involuntary movements as regular, consistent and purposive sequence of movements and it is the neural power of organism (Sevim, 2010). Learning and developing of all athletic abilities and reaching a certain level of efficiency and to do revelant technique in a smooth, quick, safe and nice form as suitably purpose is became apparent with the concept of coordination (Dündar, 2003). All motoric skills are intertwined in sporting activities. Motoric skills that lead to success in sports can not be considered separately for all sports, including gymnastics. An athlete with insufficient agility can not be expected to succeed in a sports branch which necessites perfect coordination (Çoknaz et al., 2006). Or an athlete with insufficient leg muscle power, explosive power or flexibility of muscles that included in jumping can not execute a decent jumping performance (Çoknaz et al., 2008). Therefore, the relationship between motoric skills always attracted the attention of researchers and various studies are conducted in this context (Taşkin et al., 2015). Haslofça et al. (2006) examined the relationship between physical convenience parameters in girls at the age of 7-8. They found a found a statistically significant negative correlation $(p<0.01)$ between the balance and power, power and speed.

Tasskın et al. (2015) examined the relationship between selected motor skills of footballer children and they found that there is a statistically significant relationship in the same direction between splash force, thirty seconds, push-ups, flexibility, vertical jump with 30 seconds of push-ups, flexibility, thirty-second and thirty seconds shuttle push-ups. Kuzucuoğlu (1996) reported a statistically significant relationship $(\mathrm{p}<0.019)$ between all parameters regarding flexibility, strength and speed tests and their performances for artistic gymnasts in his work with male gymnasts.

Starting from this point of view, the aim of this study is to determine some motoric parameters of pre-school gymnasts and to investigate the relationship between them.

\section{MATERIALS AND METHOD}

This study is conducted on 30 pre-school rhythmic gymnasts aged $(7.23 \pm 1.50)$ years, heighted $(122.33 \pm$ $10.00) \mathrm{cm}$, body weighted $(24.81 \pm 7.68) \mathrm{kg}$ who hasengaged in rhythmic gymnastics for 2 years in Gazi College Sports Club. Eurofit Physical Ability Test was applied to the subjects (Eurofit Bedensel Yetenek Testleri El Kitabi. 1988). Measurements are taken at Gazi College gym. Permission regarding the study is taken from the families of all gymnasts. Application of the test protocol is described in detail to the subjects. Measurements are taken after 15 minutes warmup session and lasted for a week. Measurements regarding resting heart rate, blood pressure, height, weight, filamingo balance test, tapping plate, standing long jump, 30 seconds sit-up test, reaction tests, sit and reach flexibility test, hand dynamometer, bent arm hang and 10x5 m run. Filamingo Balance Test: The subjects stand on a beam with the length of $50 \mathrm{~cm}$, the height of $4 \mathrm{~cm}$, the width of $3 \mathrm{~cm}$ and try to stand in balance for 1 minute. While balancing on the preferred leg, the free leg is flexed. Instructor stops the stopwatch each time the balance is lost. Everytime the subject loses her balance the test is stopped. Plate Tapping Test: Two discs with $20 \mathrm{~cm}$ diameters are placed on the table horizontally with $6 \mathrm{~cm}$ distance. Two rectangles sized 10x20 cm are 
Pedagogical Research, 3(3), 09

Table 1. Descriptive Statistics

\begin{tabular}{lcc}
\hline Variables & Average & Std. Deviation \\
\hline Age (years) & 7,23 & 1,50 \\
\hline PR (pulse/min.) & 102,33 & 12,06 \\
\hline Blood Pressure(mm Hg) & $9,80 / 5,76$ &, $99 /, 85$ \\
\hline Height (cm) & 122,33 & 10,00 \\
\hline Weight (kg) & 24,81 & 7,68 \\
\hline Filamingo Balance & 11,56 & 13,25 \\
\hline Plate tapping (sec) & 10,11 & 2,40 \\
\hline Long Jump (cm) & 89,97 & 19,76 \\
\hline Sit-up (number) & 14,63 & 6,48 \\
\hline 10x5 m (sec) & 54,26 & 11,19 \\
\hline Sit and reach (cm) & 27,03 & 3,97 \\
\hline Hand Dynamometer (Right) & 9,51 & 3,58 \\
\hline Hand Dynamometer (Left) & 9,42 & 3,46 \\
\hline Bent arm hang (sec) & 3,17 & 3,51 \\
\hline
\end{tabular}

Table 2. The table of correlation between variables

\begin{tabular}{llll}
\hline Variables & & p-value & Relation Coefficient \\
\hline Long Jump & $10 x 5 \mathrm{~m}$ &, $001^{*}$ & $-0,573$ \\
\hline Plate Tapping & Long Jump &, $004^{*}$ & $-0,51$ \\
\hline Filamingo & Long Jump &, $016^{*}$ & 0,436 \\
\hline Filamingo & Plate Tapping &, $013^{*}$ & $-0,447$ \\
\hline Plate Tapping & Sit and reach &, $024^{*}$ & $-0,411$
\end{tabular}

*p-value $<0,05$ Relation is significant

placed into each disc. The preferred hand is placed on the rectangle. The subject moves the other hand back and forth between the discs and touch them as quickly as possible. This action is repeated for 25 full cycles and the duration is recorded in terms of seconds (Eurofit Bedensel Yetenek Testleri El Kitabi. 1988). Sit and Reach Flexibility Test: It is performed while sitting on the floor with legs stretched out straight ahead. The soles of the feet are placed flat against the flexibility board. The subject tries to push the measuring line as far as possible. Best result of two trials is recorded (Tamer, 2000). Standing Long Jump Test: The subject stands behind a line marked on non-slippery ground. A two foot take-off and landing is used, with swinging of the arms and bending of the knees to provide forward drive. The subject attempts to jump as far as possible, landing on both feet without falling backwards. The maximum distance is recorded as meters. (Eurofit Bedensel Yetenek Testleri El Kitabi. 1988). Hand Dynamometer. The subject holds the dynamometer in the preferred hand. When ready the subject squeezes the dynamometer with maximum effort. Best result of two trials is recorded (Tamer, 2000). The 30 seconds Sit-up Test: It is performed as sitting as soles are adjacent with mat, knees bent (90), hands clenched in the neck and shoulders are touching with the gorund lying supine and elbows to touch the knees after the command. Number of movements were recorded until 30 seconds Subject lies on the mat with soles on the floor and knees bent. The fingers should be interlocked at the back of the neck and shoulders should be touching the ground. The subject raises her chest by command and comes into a position where elbows can touch the knees. The maximum number of correctly performed sit-ups for 30 seconds is recorded (Eurofit Bedensel Yetenek Testleri El Kitabi. 1988). Bent Arm Hang: Subjects are lifted up at the horizontal bar by the instructor until their chins pass the bar line by assisted as holding the bar. They are then required to hold this position as long as possible.. Test is ended when level of eyes are below the bar. (Eurofit Bedensel Yetenek Testleri El Kitab1. 1988) $10 X 5 \mathrm{~m}$ : It is the sprint which is made as quickly as possible between the two lines 5 meters away from each other. The subject's feet should not cross the lines during the test. The results of the 5 runs between the lines are recorded by seconds.

Firstly, descriptive statistics is performed for all data. In order to determine the relationship between some parameters, Pearson Correlation coefficient is calculated to investigate the direction and strength of the linear relation for normally distributed data and Spearman Correlation coefficient is calculated for data not distributed normally. Significance level is considered as $\mathrm{p}<0,05$. Values are given as mean \pm standard deviation (sd).

\section{RESULT}

Descriptive statistics regarding 30 pre-school gymnasts are given in Table 1, also the relationship between variables are given in the Table 2 in detail. The gymnasts' age is calculated as ( $7.23 \pm 1.50)$ years, height is calculated as $(122.33 \pm 10.00) \mathrm{cm}$, body weight is calculated as $(24.81 \pm 7.68) \mathrm{kg}$, filamingo balance performance is calculated as $(11.56 \pm 13.25)$, plate tapping speed is calculated as $(10.11 \pm 2.40)$ sec, long jump distance is calculated as (89.97 $\pm 19.76) \mathrm{cm}$, sit-up performance is calculated as $(14.63 \pm 6.48)$ times, $10 \times 5 \mathrm{~m}$ running time is calculated as $(54.26$ 
$\pm 11.19) \mathrm{sec}$, sit and reach distance is calculated as $(27.03 \pm 3.97) \mathrm{cm}$, bent arm hang time is calculated as $(3.17 \pm$ 3.51) sec. There is a relation between $10 \times 5$ and long jump parameters ( $\mathrm{p}$-value $=0.001$ ). The relation is mid level with $53.7 \%$ and has reverse direction. There is a relation between plate tapping test and long jump parameters ( $\mathrm{p}-$ value $=0.004)$. The relation is mid level with $\% 51$ has reverse direction. There is a relation between long jump and Filamingo parameters $(\mathrm{p}$-value $=0.016)$. The relation is mid level with $43.6 \%$ and has same direction. There is a relation between plate tapping and Flamingo parameters $(\mathrm{p}$-value $=0.013)$. The relation is mid level with $44.7 \%$ and has reverse direction. There is also a relation between plate tapping and sit and reach parameters ( $\mathrm{p}$-value $=$ 0.024). The relation is mid level with $41.1 \%$ and has reverse direction.

\section{DISCUSSION}

In the study, some motoric parameters of pre-school athletes were determined and relations between these paramteres are examined. As a result, a mid level and reverse relation is found between long jump distance, 10x5 running time and plate tapping speed. However only a same directioned relation is found between long jump distance and filamingo balance performance. Besides, a mid level and reverse directed relation is found between plate tapping speed, filamingo balance performance and sit and reach distance. When physical parameters such as age, height and body weight are evaluated, results as $7.23 \pm 1.50$ years, $122.33 \pm 10.00 \mathrm{~cm}, 24.81 \pm 7.68 \mathrm{~kg}$ are similar to Đorđević et al. (2014) $7.20 \pm$ 0:40 year, $125.41 \pm 5.9 \mathrm{~cm}$, Çelik et al. (2013) $124.03 \pm 3.65 \mathrm{~cm}$ and 23.20 $\pm 3.53 \mathrm{~kg}$ and also a few different studies. On the other hand, sit and reach distance is found as $27,03 \pm 3,97 \mathrm{~cm}$. Saygin and Mengütay (2006) found as this parameter as 18,57 $\pm 6,94 \mathrm{~cm}$, Çelik et al. (2013) found it as 24,32 $\pm 3,81$ $\mathrm{cm}$ and Koç and Tekin (2011) found it as $20.94 \pm 4.69 \mathrm{~cm}$. It is clear that flexibility values of gymnasts are higher than those at the same age who are not gymnasts. It is considered to stem from the fact that flexibility is one of the most important motoric abilities gymnastics neccesitates. Regular gymnastics trainings have improving effect on flexibility on children. The sit-up test results are found as 14,63 \pm 6.48 units in the study. and Çelik et al. (2013) found it as 17,37 $\pm 2,98$ units, Haslofça et al. (2006) found it as 13,63 $\pm 4,81$ units, Turgut and Çetinkaya (2013) found it as 15,98 $\pm 7,34$ units and also Koç and Tekin (2011) found 12.52 \pm 3.43 units. The results of the study seem to be consistent with the literature. Little differences are considered to stem from differences in trainings. 10x5 m value is found as $54,26 \pm 11,19 \mathrm{sec}$ in the study. Đorđević et al. (2014) found it as 18,98 $\pm 2,2 \mathrm{sec}$, Haslofça et al. (2006) found it as $25,61 \pm 2,34 \mathrm{sec}$. The results obtained in this study appears to be rather higher than the results of other studies. Speed is important in rhythmic gymnastics not only in terms of execution of technical structure, but also in terms of increase of speed in sequential movements (Doğan and Altay, 1996). Therefore it is thought that more effort should be needed in trainings, to improve speed. In the study long jump distance of gymnasts is found as $89,97 \pm 19,76 \mathrm{~cm}$. Akınbay (2014) found standing long jump value of pre-school children as $73,95 \pm 13,19$ in his thesis, Koç and Tekin (2011) found it as $117,73 \pm 8,88 \mathrm{~cm}$. Haslofça et al. (2006) found it as 100,36 $\pm 17,26 \mathrm{~cm}$, Turgut and Çetinkaya (2006) found it as $94,73 \pm 14,45 \mathrm{~cm}$. The results of the study seem to be consistent with the literature. In the study, bent arm hangvalue is found as 3,17 $\pm 3,51 \mathrm{sn}$. Koç and Tekin (2011) found bent arm hang value of children at the average age of $7.05 \pm 0.22$ as $20,42 \pm 13,20 \mathrm{sec}$. Gymnastics necessitates athletes to move their body from someplace to another one most of the time (Sayin, 2000). Therefore, arm strength and arm's function to move the body is important. However, results of our study, seem to be very low compared to other results in the literature. Strength should be one of the most important basic motor skills necessary to be improved in gymnastics trainings and the trainings should be planned taking this into account. Filamingo balance performance value of the gymnasts is found as $11.56 \pm 13.25$. Koç and Tekin (2011) found this value as 13,78 \pm 4 ,

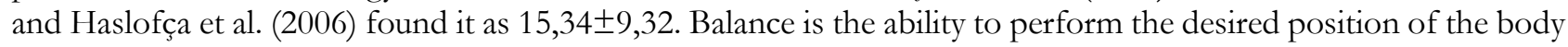
during the movement (Tot, 2009). Balance is considered as performance determiner in rhytmic gymnastics. It is very important when landing on the floor after jumps, in acrobatic techniques and in rotations (Doğan and Altay, 1996). It is seen in a study that gymnasts' balance performance is better than the football and basketball players' performance (Erkmen et al., 2007). Aydin et al. compared gymnasts and a control group by keeping them in balance on one foot on a semi hard floor, eyes opened and closed. They concluded that gymnasts can keep their balance with fewer faults. In the study, plate tapping speed is found as 10,11 $\pm 2,40 \mathrm{sec}$. Koç and Tekin (2011) found the arm movement speed of children at the average age of $7.05 \pm 0.22$ as 12.95 $\pm 4.21 \mathrm{sec}$ (Koç and Tekin, 2011). Haslofça et al. (2006) examined the relations between physical fitness parameters of girls at the age of 7-8 and negaive correlation is found statistically significant between balance and standing long jump values $(\mathrm{p}<0.01)$.

\section{REFERENCES}

Akınbay, H. (2014). Okul Öncesi Dönemde Oyunun Önemi ve Çocukların Motor Gelişimi Üzerine Etkileri. Selçuk Üniversitesi Sağhl. Bilimleri Enstitüsü Yülesek. Lisans: Konya. 
Bağc1, E., Suveren, S. and Ünal, H. (2006). 9-11 Yaş Grubu Artistikçi Bayan Sporcular İle Aynı Yaş Grubu Ritmik Cimnastikçilerin Bazı Fiziksel ve Kondisyonel Özelliklerinin Karşılaştırılması. 9. Uluslararası Spor Bilimleri Kongre Kitabr, 211-213.

Bulca, Y. and Ersöz, G. (2004). Ritmik Cimnastikçilerde Egzersiz ve Beslenmenin Büyümeye Etkileri. Gaæi Beden Eğitimi ve Spor Bilimleri Dergisi, 2, 11-12.

Çelik, A., Günay, E. and Aksu, F. (2013). 7-9 Yaş Grubu İlköğretim Öğrencilerinin Fiziksel Ve Motorik Özelliklerinin Değerlendirilmesi. Dë̈ T⿰р Fakïltesi Dergisi, 1, 7 -13.

Çoknaz, H., Tıkız, D. and Altay, B. (2006). Elit Erkek Cimnastikçilerde Esneklik, Sürat ve Çabukluk İlişkisi. 9. Uluslararası Spor Bilimleri Kongre Kitabi; Muğla, 167-168.

Çoknaz, H., Yıldırım, N. Ü. and Özengin, N. (2008). Artistik Cimnastikçilerde Farklı Germe Sürelerinin Performansa Etkisi. Spormetre Beden Eğitimi ve Spor Bilimleri Dergisi, 3, 151-157. https://doi.org/10.1501/Sporm_0000000100

Doğan, F. and Altay, F. (1996). Sportif Ritmik Cimnastik. Ankara.

Doğan, F. (1986). Ritmik Cimnastik. Seldem Ofset; Ankara.

Đorđević, M., Pantelić, S., Kostić, R. and Uzunović, S. (2014) Correlation Between Anthropometric Characteristics and Motor Abilities in Seven-Year-Old Girls. Physical Education and Sport, 3, 251-260.

Dündar, U. (2003). Antrenman Teorisi. 6. Bask1. Nobel Yayın Dağıtım; Ankara.

Elibol, Z. (2000). Ritmik Cimnastikçilerin Bazı Fiziksel Uygunluk ve Antropometrik Özelliklerinin Değerlendirilmesi. Gaz̧i Üniversitesi Sağllk Bilimleri Enstitüsü Yüksek Lisans: Ankara.

Erkmen, N., Suveren, S., Göktepe, A. S. and Yazıcıoğlu, K. (2007). Farklı Branşlardaki Sporcuların Denge Performanslarının Karşılaştırıması. Spormetre Beden Eğitimi ve Spor Bilimleri Dergisi, 3, 115-122. https://doi.org/10.1501/Sporm_0000000080

Eurofit Bedensel Yetenek Testleri El Kitabi. (1988). Roma.

Günay. M., Tamer, K. and Cicioğlu, İ. (2006). Spor Fišyolojisi ve Performans Ölçümü. Ankara.

Haslofça, E., Haslofça, F. and Kutlay, E. (2006). 7-8 Yaş Grubu Kız Çocuklarında Fiziksel Uygunluk Parametreleri Arasındaki İlişkinin İncelenmesi. 9. Uluslararası Spor Bilimleri Kongre Kitabı, 335-338.

Koç, H. and Tekin, A. (2011). Beden Eğitimi Derslerinin Çocuklarda Seçilmiş Motorik Özellikler Üzerine Etkisi. Yüzüncü Yal Üniversitesi Ë̈itim Fakültesi Dergisi Özel Sayısi, 9-17.

Konter, A. (1998). Sportif Ritmik Cimnastik. İstanbul.

Kutlay, E. (1999). Ritmik Cimnastikte Yetenek Seçimi ve Yönlendirilmesinde Dikkat Edilecek Hususların İncelenmesi. Dokuz Eylül Üniversitesi Sağhlk Bilimleri Enstitüsü Yüksek Lisans: İzmir.

Kuzucuoğlu, T. (1996). Elit Cimnastik Sporcularının Fizyolojik Parametrelerinin Kuvvet Parametreleri İle Mukayesesi. Inönü Üniversitesi Sağglk Bilimleri Enstitüsü Yüksek Lisans: Malatya.

Mengütay, S. (1998). Artistik Cimnastik. Temel Hareketlerin Ögrretim Yöntemleri ve Yardım Şekilleri. Ankara.

Özer, K. (1989). Artistike Cimnastike Antrenmanmm Temelleri. GSGM Spor Eğitim Dairesi Yayınlar1 91; Ankara.

Santos, A. B., Lemos, M. E., Lebre, E. and Carvalho, L. A. (2015). Active and Passive Lower Limb Flexibility in High Level Rhythmic Gymnastics. Science of Gymnastics Journal, 2, 55-66.

Saygin, Ö. and Mengütay, S. (2006). Çocuklarda Fiziksel Aktivite ve Fiziksel Uygunluk Arasındaki İlisskinin Araştırılması. 9. Uluslararası Spor Bilimleri Kongre Kitabı, Muğla, 371-373.

Sayın, M. (2000). Artistik Cimnastik İlk ve Orta Öğrenim Kuruymlarında Zorlunlu Seerilerinin Öğretim Yöntemi. Türkiye Cimnastik Federasyonu Dergisi, 14, 17-23.

Sevim, Y. (2010). Antrenman Bilgisi. 8. Bask1. Fil Yayınevi; Ankara

Sevinç, H. (2008). 10-14 Yaş Grubu Çocuklara Uygulanan Futbol Beceri Antrenmanının Temel Motorik Özelliklere ve Antropometrik Parametreler Etkisi. Niğde Üniversitesi Sağhlk Bilimleri Enstitïsü Yü̈ksek Lisans: Niğde.

Tamer, K. (2000). Sporda Fiziiksel Fišolojik Performansin Ölçülmesi ve Değerlendirilmesi. Bağırgan Yayınevi; Ankara,

Taşkın, C., Karakoç, Ö., Nacaroğlu, E. and Budak, C. (2015). Futbolcu Çocuklarda Seçilmiş Motorik Özellikler Arasındaki İlişkinin İncelenmesi. Spor ve Performans Arastrmalar Dergisi, 2, 101-107.

Tot, T. (2009). Elit Erkek Basketbol ve Hentbolcuların Antropometrik Ölçümleri ve Vücut Yağ Oranları İle Denge Düzeyleri Arasındaki İlişkinin Karşılaştırılması. Gaži Üniversitesi, Sağllk Bilimleri Enstitüsü Yü̈ksek Lisans: Ankara,

Turgut, A. and Çetinkaya, V. (2006). 6-11 Yaş Arası Kız Çocuklarda Bazı Motor Özelliklerinin Belirlenmesi. 9. Uluslararası Spor Bilimleri Kongre Kitabı, Muğla, 186-188.

Ünal, H., Zorba, E., Saygın, Ö., Altay, B., and Bağcı, E. (2006). Aynı Antrenman Cetveline Sahip Milli ve Milli Olmayan Erkek Cimnastikçiler Arasındaki Bazı Fiziksel Uygunluk Parametrelerinin Karşılaştırılması. 9. Uluslararası Spor Bilimleri Kongre Kitabı, Muğla: 437-440. 